\title{
Effects of the COVID-19 pandemic on obstetrics and gynecology residency training in Turkey
}

\section{COVID-19 pandemisinin kadın hastalıkları ve doğum asistalı eğitimi üzerindeki etkileri}

\author{
(D) Göknur Topçu1, (1) İpek Betül Özçivit² , (D Selçuk Erkılınç3 \\ ${ }^{1}$ Kaçkar State Hospital, Clinic of Obstetrics and Gynecology, Rize, Turkey \\ 2İstanbul University Cerrahpaşa-Cerrahpaşa Faculty of Medicine, Department of Obstetrics and Gynecology, İstanbul, Turkey \\ 3Isparta City Hospital, Clinic of Gynaecologic Oncology, Isparta, Turkey
}

\begin{abstract}
Objective: This study aimed to evaluate the effect of the coronavirus disease-19 (COVID-19) pandemic on obstetrics and gynecology residency in Turkey. Materials and Methods: A 40-item questionnaire was prepared by the European Network of Trainees in Obstetrics and Gynecology. The survey included four parts, namely, workload, training aspects, trainees' health and safety, and women's and maternal health, conducted between April 2020 and September 2020. The submission of the questionnaire was voluntary.

Results: A total of 103 trainees from 28 cities responded to the survey. The mean duration of training was 2.5 years, and first- to fifth-year residents were included. In this study, 66 trainees (65.3\%) were deployed in COVID-19 units, and the number of working hours was 84 hours per week. Moreover, $67 \%$ of the trainees reported insufficient outpatient clinic experience to meet education targets. Almost all trainees (101 of 103) trainees reported that the number of surgeries and/or elective surgeries decreased or were canceled. In addition, $63 \%$ and $68 \%$ of the trainees reported that their surgical skills were hindered by the reduced number of surgeries and dissatisfaction by not achieving a sufficient number of surgeries, respectively. Overall, $71 \%$ ( $\mathrm{n}=73$ ) were worried about their training. Only 45 trainees (43.6\%) have raised their concerns to their program coordinators. Trainees in Turkey experienced a decrease in the workload during the first COVID-19 wave by $62 \%(\mathrm{n}=64)$. In average, trainees worked nearly $30 \mathrm{~h}$ less than their usual workweek. Only $5 \%$ of the trainees $(\mathrm{n}=5)$ worked from home. Trainees claimed to have used sufficient personal protective equipment, and 66\% ( $\mathrm{n}=68$ ) could keep their social distance in the hospital. The availability of health care was different between departments, and the family planning and reproductive medicine departments were the most affected.

Conclusion: The obstetrics and gynecology training in Turkey has significantly been affected by the COVID-19 pandemic.
\end{abstract}

Keywords: COVID-19, gynecology, obstetrics, residency, training, Turkey

Öz

Amaç: Bu çalışmanın amacı, koronavirüs hastalığı-19 (COVID-19) pandemisinin Türkiye'deki Kadın Hastalıkları ve Doğum uzmanlık eğitimine etkisini değerlendirmektir.

Gereç ve Yöntemler: Avrupa Kadın Doğum ve Hastalıkları Asistan Organizasyonu (ENTOG) tarafından 40 maddelik bir anket hazırlandı. Anket 4 bölümden (iş yükü, eğitim konuları, stajyerlerin sağlığı ve güvenliği, kadın ve anne sağlı̆̆ı) oluşmuştur. Türkçe çevirisi Türkiye'deki asistanlara Nisan 2020 ile Eylül 2020 iletilmiştir. Ankete katılım gönüllülük esasına dayanmıştır.

Bulgular: Anketimizi 28 farklı şehirden toplam 103 asistan yanıtladı. Ortalama eğitim yılı 2,5 idi ve bu çalışmada tüm yıllardan asistanlar temsil edildi. COVID birimlerinde çalışma 66 asistan $(\% 65,3)$ tarafından bildirildi. Haftada 84 saate kadar çalışıldığı belirlendi. Eğitim hedeflerine ulaşmak için yetersiz poliklinik deneyimi asistanların \%67'si tarafından rapor edildi. Asistanların neredeyse tamamı (103 kişiden 101’i) ameliyat sayısının azaldığını veya iptal edildiğini bildirdi. Ameliyat sayısının azalması nedeniyle engellenen cerrahi beceriler ve yeterli sayıda ameliyat yapılmamasından kaynaklanan memnuniyetsizlik asistanların sırasıyla \%63 ve \%68'i tarafından bildirilmiştir. Asistanların \%71'i eğitimleri konusunda endişeliydi. Sadece 45 asistan $(\% 43,6)$ program koordinatörleri ile endişelerini paylaşabilmiş. Türkiye'deki asistanlar ilk COVID-19 dalgasında iş yükünde \%62 (n=64) azalma yaşadı. Ortalama olarak, asistanlar normal çalışma haftalarına kıyasla neredeyse 30 saat daha az çalıştı. Asistanların sadece \% $5^{\prime} \mathrm{i}(\mathrm{n}=5)$ evden çalışırken, yeterli

PRECIS: The obstetrics and gynaecology training in Turkey has significantly been affected by the COVID-19 pandemic. Decrease in the learning opportunities of trainees may lead to decrease in the quality of care.

Address for Correspondence/Yazışma Adresi: Göknur Topçu MD, Kaçkar State Hospital, Clinic of Obstetrics and Gynecology, Rize, Turkey

Phone: +90 5366081613 E-mail: goknurtopcu@gmail.com ORCID ID: orcid.org/0000-0003-1362-6224

Received/Geliș Tarihi: 27.03.2021 Accepted/Kabul Tarihi: 17.10.2021

${ }^{\circledR}$ Copyright 2021 by Turkish Society of Obstetrics and Gynecology

Turkish Journal of Obstetrics and Gynecology published by Galenos Publishing House 
kişisel koruyucu donanıma sahip olduklarını ve \%66'sı (n=68) hastanede sosyal mesafelerini koruyabildiklerini bildirdi. Sağlık hizmetlerinin mevcudiyeti bölümler arasında farklılık gösterirken en çok aile planlaması ve üreme tıbbının etkilendiği bildirildi.

Sonuç: Türkiye'deki obstetrik ve jinekoloji eğitimi COVID-19 pandemisinden önemli ölçüde etkilenmiştir.

Anahtar Kelimeler: COVID-19, jinekoloji, obstetrik, asistan, eğitim, Türkiye

\section{Introduction}

Turkish Trainees in Obstetrics and Gynaecology (TTOG) is a member of the European Network for Trainees in Obstetrics and Gynaecology (ENTOG), which is an organization that aims to improve and harmonize training in obstetrics and gynecology across Europe with 35 member countries, ultimately improving women's health (ENTOG.eu 2020).

Coronaviruses, belonging to Nidovirales order, are enveloped non-segmented positive-sense RNA viruses. They are responsible for the severe acute respiratory syndrome coronavirus (SARS-CoV) outbreak in 2002, the ongoing middle East respiratory syndrome-related-CoV outbreak since 2012, and the COVID-19 outbreak (SARS-CoV-2) as declared by World Health Organization on March 11, 2020 (1,2).

Since the announcement of the first positive case in Turkey, the COVID-19 pandemic has had serious consequences on the physical and mental health of both the people and the economy ${ }^{(3)}$.

It has become the main reason for stress and anxiety among health workers because of the uncertainty of the longterm complications and the lack of treatment algorithms. Furthermore, the steady increase in the workload, fear of transmission, and prolongation of the pandemic are additional factors that lead to burnout syndrome and depression among health workers ${ }^{(4)}$.

As of mid-August 2021, more than 6.02 million cases and 52,703 deaths have been recorded in Turkey ${ }^{(5)}$. To cope with this unpredictable situation, the Turkish healthcare system has been rearranged to optimize its resources, and serious precautions have been taken against the spread of infection, such as lockdowns and travel restrictions. With these modifications, nearly all hospitals in Turkey have turned into pandemic hospitals, where all elective appointments and surgeries have been canceled. All educational meetings and programs have been either canceled or shifted online.

This study aimed to evaluate the effect of the COVID-19 pandemic on the residency training programs of obstetrics and gynecology in Turkey. To the best of our knowledge, this is the first study from Turkey on the effect of COVID-19 on training programs.

\section{Materials and Methods}

\section{Study Design}

This cross-sectional exploratory survey study aimed to investigate the effect of the COVID-19 pandemic on the training and workload of Turkish trainees in obstetrics and gynecology and women's health through an online questionnaire survey.

\section{Questionnaire}

The online survey was prepared by using Google Forms consisting of 40 questions including multi-answer, multiplechoice, open-ended, and 10-point Likert scale items. The survey was divided into four parts: Part 1, workload; Part 2, training aspects in obstetrics and gynecology; Part 3, health and safety of the trainee; and Part 4, women's health and maternal health issues (including care given in obstetrics, family planning, reproduction, gynecology, and gynecologic oncology departments). The demographic data of the respondents, such as age, years spent in residency, city, and hospital type they are having their training, were collected at the beginning of the survey. The questionnaire was shared on the TTOG website, TTOG social media, TTOG mailing system, and through TTOG hospital-based representatives. Data were collected anonymously from April 29, 2020, to September 5, 2020, by residents after obtaining their informed consent. The principles stated in the Helsinki Declaration were followed. Trainees from all years were included. The obstetrics and gynecology training program in Turkey lasts for 4 years and can be extended for another year.

The survey enabled the trainees to compare their involvement in training activities (outpatient visits, diagnostic procedures, laparotomy, laparoscopic gynecological surgeries, etc.) between the pre-COVID-19 and COVID-19 periods.

\section{Translation}

The original version of the questionnaire was in English and then translated to Turkish to overcome the language barrier. Data collected in Turkish was not used in the ENTOG report. Trainees who have not completed the original English survey were asked to complete the Turkish version.

\section{Statistical Analysis}

Data normality was evaluated using the Kolmogorov-Smirnov test or Shapiro-Wilk tests. Continuous data were compared using independent samples t-tests or Mann-Whitney U tests. Categorical data were compared with the chi-square test. A p-value $<0.05$ was regarded as significant. Statistical analysis was performed using SPSS Statistics 21 (IBM Corp., Armonk, NY, USA).

\section{Results}

\section{Characteristics}

In total, 103 trainees from Turkey have completed our survey. The respondents' age ranged from 24 to 39 (mean, 29) years. The duration of training ranged from 3 to 56 (mean, 21.25) months. The largest proportion of the respondents was working 
in Istanbul (22.3\%). Obstetrics and gynecology training can be conducted either at a university hospital or a training and research hospital. The majority of the respondents were training at a university hospital (57.3\%). National strategy against COVID-19 outbreak included partial quarantine $(81.2 \%)$ in most of the cities. Local guidelines were followed in the management of patients with COVID-19 (98\%). The national guidelines in the management of pregnant patients with COVID-19 were followed by $87 \%$ of the institutions. COVID-19 cases were managed by 66 of the respondents (65.3\%) rather than obstetrics and gynecology cases. Insufficient personal protective equipment (PPE) was reported by $60(59.4 \%)$ of the trainees. Nearly half of the respondents have received training regarding the use of PPE, and $57.4 \%$ of the respondents believed that they could still provide standard care in these circumstances (Table 1).

The respondents felt well-prepared in the management of patients with COVID-19. Physical and psychosocial health and feeling safe were rated as 4 and 6 of 10, respectively (Table 2).

\section{Survey Results}

The workload decreased according to 63 (62.4\%) respondents, while it remained unchanged or increased according to $18.8 \%$ and $18.8 \%$ of the respondents, respectively (Graph 1). The resting hours during and after work were different among trainees, as shown in Graph 2.
The number of obstetrics and gynecology patients has decreased during the COVID-19 pandemic. According to more than half of the respondents (53\%-52.5\%), the number decreased between 25\% and 75\% (Graph 2). The number of outpatients was not enough to meet training requirements according to 68 (67.3\%) respondents. A decrease in the number of surgeries was reported by 99 (98\%) respondents. Furthermore, while 72 (71.3\%) residents were concerned about their education, only $43(42.6 \%)$ had reported their concern to their professor/head of training/ head of department (Graph 2). The concern about the training was independent of the stage of training $(\mathrm{p}=0.258)$ (Table 3).

Regarding the health and safety of the trainees, protective measures were taken. Keeping social distance inside the hospital was reported possible by 68 (67.3\%) respondents. The application of COVID-19 tests was possible in case of contact with patients with COVID-19 (40.6\%) or in case of fever $(10.9 \%)$ and minor symptoms (12.9\%). Most of the respondents $(67.3 \%)$ knew what to do when they started to exhibit COVID-19 symptoms (Graph 3). By contrast, 23.8\% of the trainees reported no special instructions, and $61.4 \%$ reported that no attention was given for the provision of psychosocial support to the healthcare staff.

Trainees (46.5\%) were assigned in COVID-19 intensive care units (ICUs) without any training. Insufficient training in the management of obstetric COVID-19 cases was reported by $76(75.2 \%)$ respondents. We analyzed the duration spent at

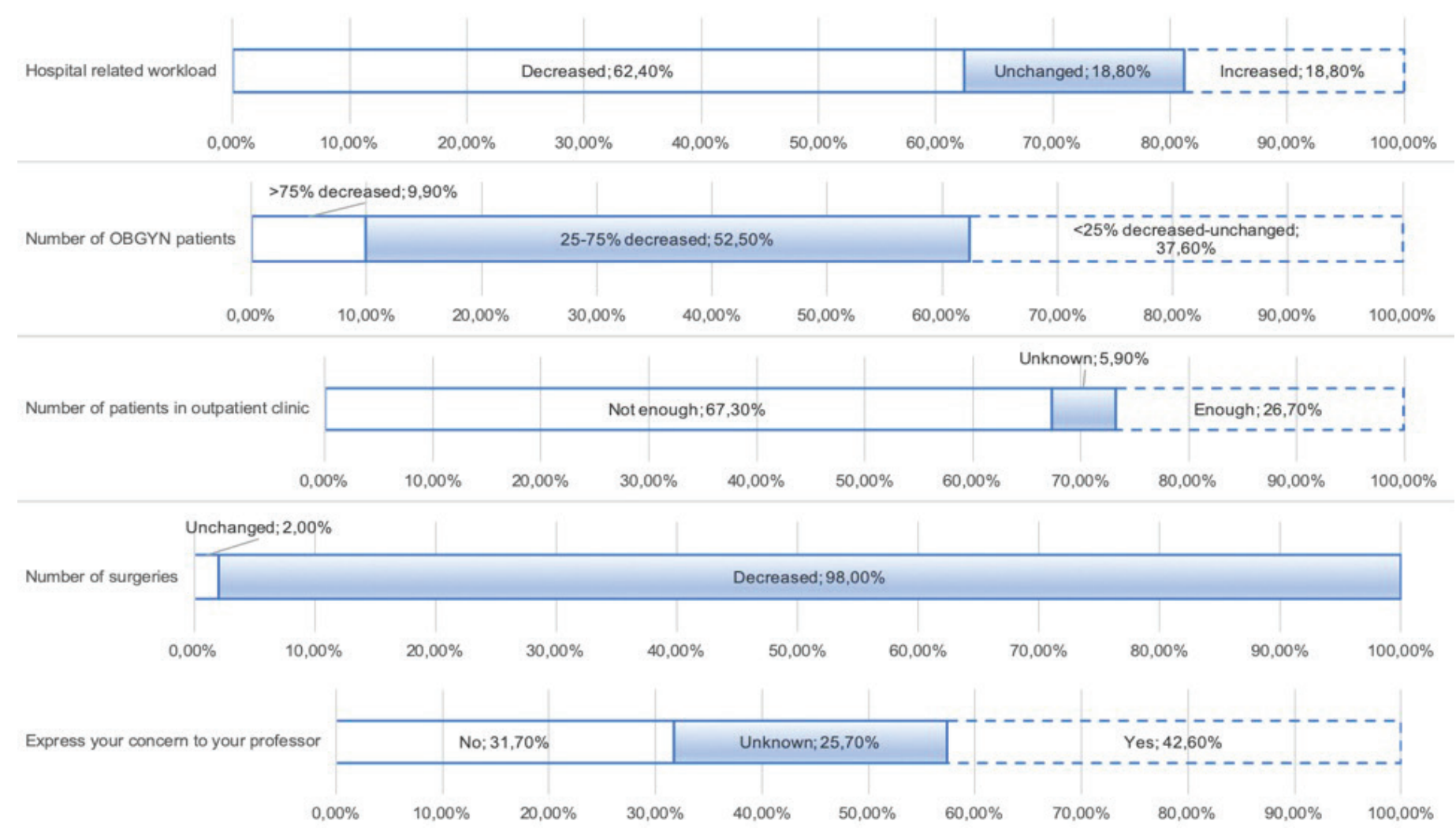

Graph 1. Workload during the pandemic 


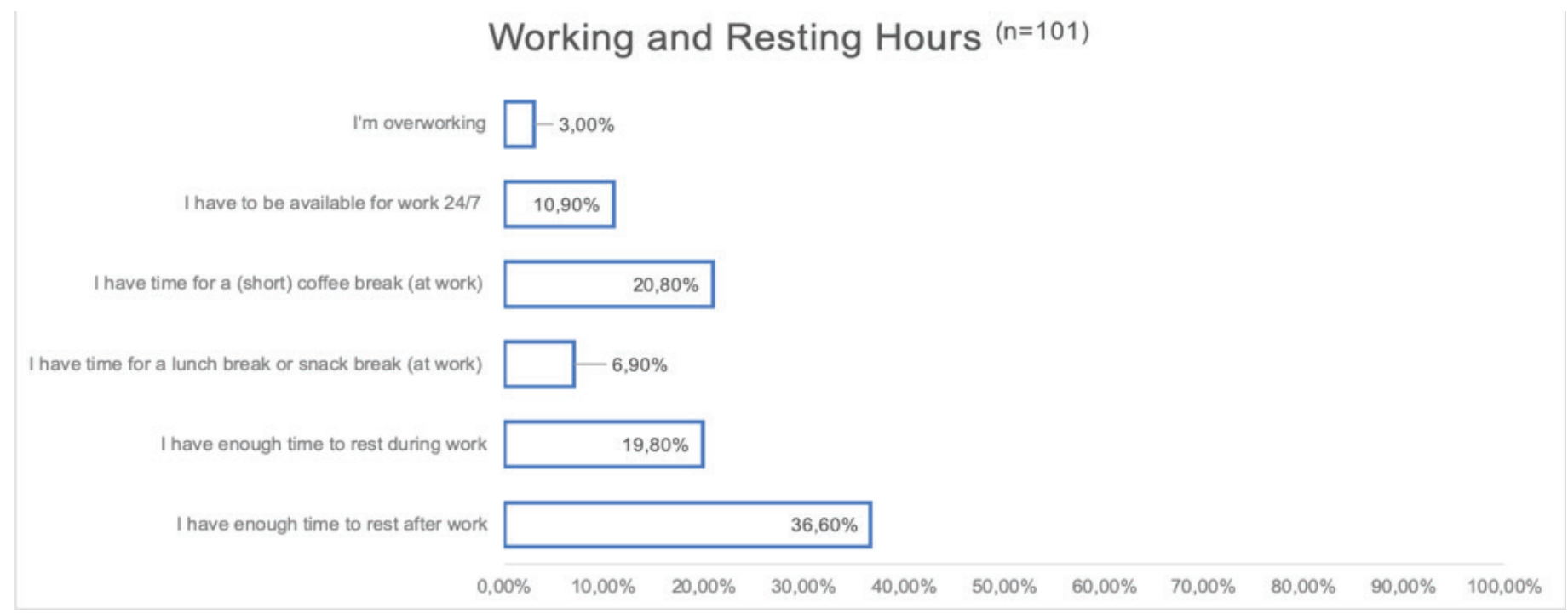

Graph 2. Working and resting hours

Table 1. Characteristics of the respondents

\begin{tabular}{|c|c|}
\hline & Mean $\pm \operatorname{SD}^{(\mathrm{n}=103)}$ \\
\hline Age & $29 \pm 4$ \\
\hline Duration of training (months) & $21.25 \pm 16$ \\
\hline $\begin{array}{l}\text { Feeling well-prepared in the management } \\
\text { of COVID-19 cases }(0-10)\end{array}$ & $4.33 \pm 2.23$ \\
\hline $\begin{array}{l}\text { Feeling healthy at the moment (physically } \\
\text { and psychologically) }(0-10)\end{array}$ & $6.24 \pm 2.15$ \\
\hline Feeling safe at work $(0-10)$ & $4.02 \pm 2.16$ \\
\hline
\end{tabular}

Overall $N(\%)^{(\mathrm{n}=103)}$

\begin{tabular}{|ll|}
\hline City & $23(22.3 \%)$ \\
\hline İstanbul & $6(5.8 \%)$ \\
Ankara & $16(15.5 \%)$ \\
İzmir & $58(56.3 \%)$ \\
\hline Others & \\
\hline Hospital type & $59(57.43 \%)$ \\
\hline University hospital & $44(43.6 \%)$ \\
\hline Training and research hospital & \\
\hline Managed COVID-19 cases & $66(65.3 \%) * *$ \\
\hline Yes & $35(34.7 \%)$ \\
\hline No & \\
\hline Sufficient stocks of PPE & $60(59.4 \%)$ \\
\hline Yes & $41(40.6 \%)$ \\
\hline No & $19(18.8 \%)$ \\
\hline National strategy & $82(81.2 \%)$ \\
\hline Full quarantine & \\
\hline Partial quarantine & $0(0 \%)$ \\
\hline COVID-19 management guideline & $99 \%)$ \\
\hline National & \\
\hline Local & \\
\hline
\end{tabular}

None $2(2 \%)$

Pregnancy with COVID-19 management guideline

\begin{tabular}{ll} 
National & $2(2 \%)$ \\
Local & $88(87.1)$ \\
None & $11(10.9 \%)$ \\
Providing standard care & \\
Yes & $58(57.4 \%)$ \\
No & $41(40.5 \%)$ \\
Not applicable & $2(2 \%)$ \\
CoviD-19: Coronavirus disease-19 & \\
\hline
\end{tabular}

hospital according to the year of residency. Even though before the outbreak second-year residents were spending more time at the hospital (93.72 h/week) during the outbreak, first-year residents spent significantly more time than other residents (61.53 h/week). However, no significant difference was found in the durations spent in the hospital between years of residency before and during the outbreak $(\mathrm{p}=0.57$ and $\mathrm{p}=0.674$, respectively) (Table 2). First-year residents have worked in COVID-19 units significantly longer than other residents ( $\mathrm{p}=0.003)$ (Table 3).

The COVID-19 pandemic has affected patient care as a result of all measures taken to reduce the spread of the virus. According to $47(46.5 \%)$ respondents, access to obstetric care was not affected. However, according to the same number of residents, access to obstetric care has decreased and was only available for emergent cases. Access to family planning was decreased according to 41 (40.6\%) respondents, while it was reported by $36(35.6 \%)$ as unavailable. Access to reproductive medicine was reduced in 40 (39.6\%) of the cases and was unchanged in 17 of them (16.8\%). Access to general (benign) gynecological care was affected significantly and decreased according to 45 (44.6\%) respondents, or only available for emergent cases according to 34 (33.7\%) respondents (Graph 4). 


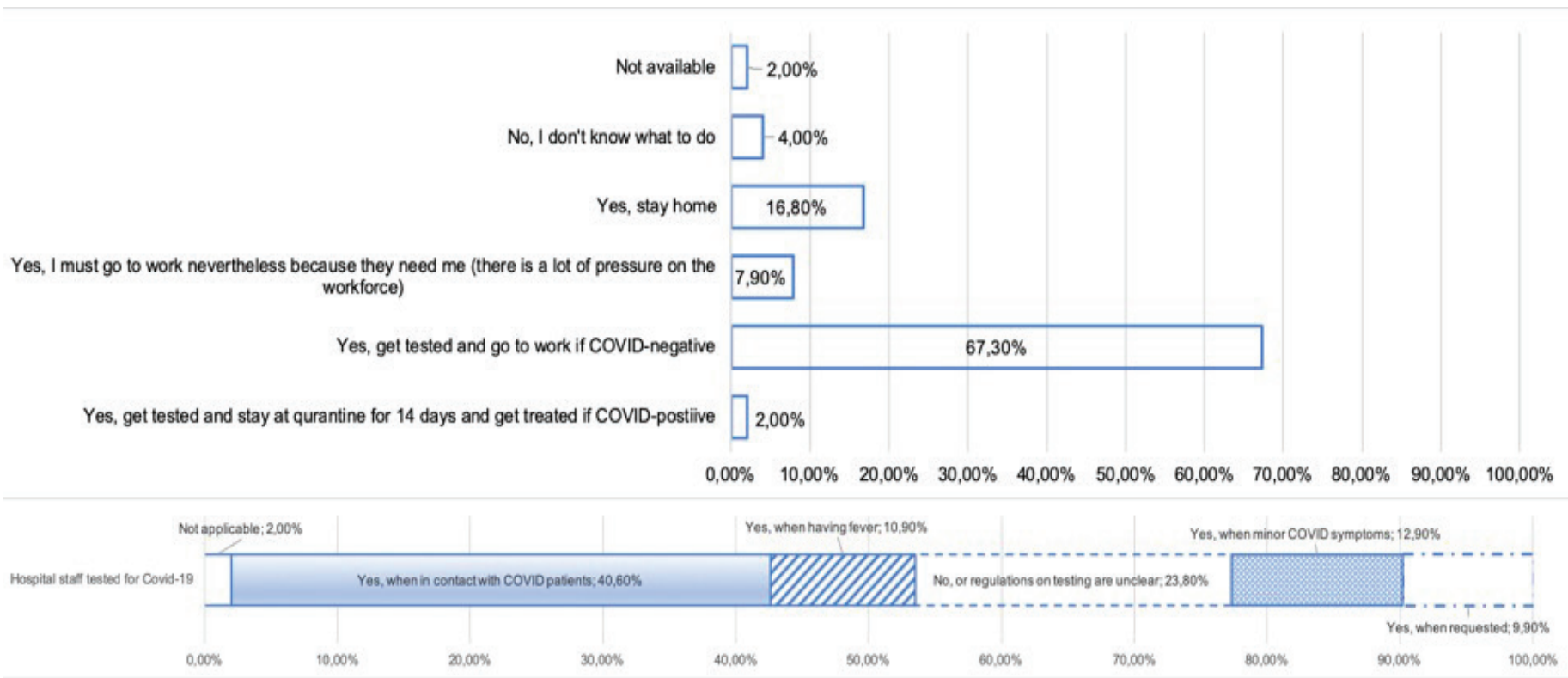

Graph 3. Readiness for the COVID-19 pandemic

COVID-19: Coronavirus disease-19

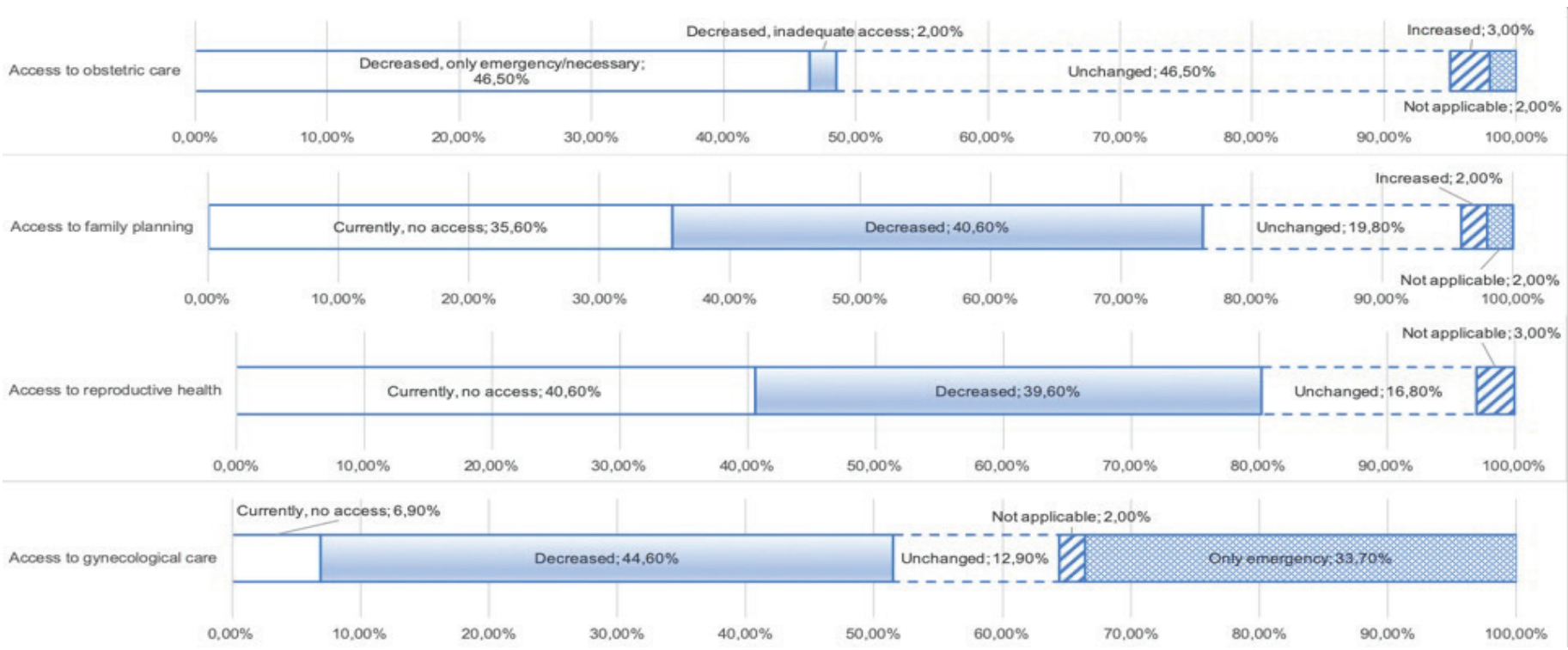

Graph 4. Access to care during the pandemic

\section{Discussion}

\section{Main Findings}

This cross-sectional study aimed to determine the effect of the COVID-19 pandemic on obstetrics and gynecology training in Turkey. Our findings showed that the COVID-19 pandemic has caused a severe impairment and disruption in the educational program of obstetrics and gynecology residency in Turkey. Until now, no measures have been taken to compensate for the disruption. This study is important as this is the first study to evaluate the effect of the COVID-19 pandemic on the training programs in Turkey.
The COVID-19 pandemic had negatively affected the Turkish healthcare system, being overwhelmed by cases in addition to routine care. Educational activities in medicine have been affected as well ${ }^{(6)}$.

The effect of the pandemic differed across the country, being more serious in crowded cities. Since most of the respondents were located in the biggest cities in Turkey, this survey may be regarded as representative of the current status of obstetrics and gynecology residency in Turkey during the pandemic.

Our results showed that approximately $70 \%$ of the trainees cared for patients with COVID-19. The first- and second-year trainees took on most of the burden during the pandemic in Turkey. Gynecologic care appeared to be more affected than obstetric 
Table 2. Difference between the times spent at the hospital before and during COVID-19 outbreak and subdivisions according to the attended year of residency

\begin{tabular}{|c|c|c|c|c|c|c|}
\hline Study variables & $\begin{array}{l}\text { First-year } \\
\text { resident }\end{array}$ & $\begin{array}{l}\text { Second- year } \\
\text { resident }\end{array}$ & $\begin{array}{l}\text { Third-year } \\
\text { resident }\end{array}$ & $\begin{array}{l}\text { Fourth-year } \\
\text { resident }\end{array}$ & $\begin{array}{l}\text { Fifth-year } \\
\text { resident }\end{array}$ & p-value $e^{\S}$ \\
\hline During COVID-19 pandemics (hours $\pm S D$ ) & $61.53 \pm 19.5$ & $59.68 \pm 20.5$ & $54.1 \pm 16.7$ & $57 \pm 26.23$ & $54 \pm 25.46$ & 0.57 \\
\hline
\end{tabular}

${ }^{\S} \mathrm{p}$ is calculated by analysis of variance, SD: Standard deviation, COVID-19: Coronavirus disease-19

$* *$ Significant at $\mathrm{p}<0.05$ level

Table 3. Difference between working at COVID-19 units and concerns about the training according to the attended year of residency

\begin{tabular}{|l|l|l|l|l|l|l|l} 
Study variables & $\begin{array}{l}\text { Firstyear } \\
\text { resident N } \\
(\%)^{(n=38)}\end{array}$ & $\begin{array}{l}\text { Second-year } \\
\text { resident N } \\
(\%)^{(n=25)}\end{array}$ & $\begin{array}{l}\text { Third-year } \\
\text { resident N } \\
(\%)^{(n=25)}\end{array}$ & $\begin{array}{l}\text { Fourth-year } \\
\text { resident N } \\
(\%)^{(n=11)}\end{array}$ & $\begin{array}{l}\text { Fifth-year } \\
\text { resident N } \\
(\%)^{(n=2)}\end{array}$ & $\begin{array}{l}\text { Overall N } \\
(\%)^{(n=101)}\end{array}$ & $\begin{array}{l}\text { p-value } \\
\text { Working at COVID-19 units }\end{array}$ \\
\hline $32(48.5 \%)$ & $15(22.7 \%)$ & $13(19.7 \%)$ & $5(7.6 \%)$ & $1(1.5 \%)$ & $66(65.3 \%)$ & $0.003^{* *}$ \\
\hline Concerned about the training & $29(40.3 \%)$ & $19(26.4 \%)$ & $14(19.4 \%)$ & $10(13.9 \%)$ & $0(0 \%)$ & $72(71.3 \%)$ & 0.258 \\
\hline
\end{tabular}

${ }^{8} \mathrm{p}$ is calculated by chi-square test, COVID-19: Coronavirus disease-19

**Significant at $\mathrm{p}<0.05$ level

care, which is not an elective care. Despite the decreased working hours of trainees relative to the pre-COVID era, the extra working time was not used for training activities. Although elective surgeries are ongoing in some centers in Turkey, most of the clinics ceased performing elective surgeries ${ }^{(7)}$. Moreover, given the reduced number of patients in outpatient clinics in urogynecology, reproductive medicine, and gynecology, the competency of trainees in these areas has been reduced. As a result, as reported by the respondents, the quality of surgical education has significantly decreased. The findings from our survey echo these situations. This issue needs to be addressed since the quality of care presented by future specialists who were trained during the pandemic has been badly affected. One possible solution to this problem is the addition of time lost during the pandemic to the routine curriculum. Increased didactic educational models, use of surgical simulators, and use of surgical videos may compensate for the gap in surgical education during the pandemic ${ }^{(8)}$. A revised national logbook must be developed for the COVID-19 era. Trainees need more support from their mentors since most of them complain about not being able to discuss their problems. Daily or weekly virtual meetings or educational courses may increase communication with the clinic and compensate for the shortcomings in education $^{(9)}$.

Emergent interventions in obstetrics and gynecology, such as emergent cesarean section or labor, make obstetrics and gynecology an emergent department. Therefore, when dealing with emergent interventions, trainees are faced with the risk of virus contamination from asymptomatic COVID-19 cases. High stress experienced during obstetrics and gynecology care increases the possibility of errors during interventions, even with fully equipped or trained staff. Our results revealed that the trainees felt unprepared to face hospital situations during the pandemic. Even though education in PPE use was given,
PPE was insufficient in most cases. Trainees should receive instructions for the care of COVID-19 and obstetric COVID-19 cases before deployment to COVID-19 ICUs or obstetric clinics, which was not the case for our respondents. Even though the Ministry of Health announced a national algorithm for obstetric cases, educational meetings are needed to reinforce the application of these algorithms ${ }^{(10)}$. One possible advantage of this pandemic is that the trainees gained information and experience on how to handle such a health crisis. The prolongation of the pandemic may affect trainees in various ways; however, increased familiarity may help them handle problems faced during a pandemic.

As study strength, this is the first study that investigated obstetrics and gynecology training during the COVID-19 pandemic in Turkey. We included residents from all regions in Turkey and represented the current status. The main limitation of the study was the lack of subgroup analysis according to the years of training of the respondents, which may have contributed to the heterogenicity of the results. The negative effect of the pandemic on obstetrics and gynecology training in Turkey can be compared with the situation in Europe or in other specialties ${ }^{(11-16)}$. In Europe, $60 \%$ of the trainees were concerned about reaching the goals in their training; in Turkey and Italy, the rates of anxiety were higher, with $71.3 \%$ and $84 \%$, respectively ${ }^{(11,12)}$. Unfortunately, unlike their colleagues in Europe (73\%), only $42.6 \%$ of the trainees in Turkey had expressed their concern to their mentors, and limited arrangements were made to overcome these shortcomings in Turkey. Our respondents and trainees in Europe reported that the workload has decreased, and this emphasizes the burden of the obstetrics and gynecology training program in the pre-COVID era ${ }^{(12)}$. In addition, respondents reported a lack of psychosocial support (61.4\%) compared with European trainees who received psychosocial support (65\%). Insufficient 
PPE was reported by $59.4 \%$ of our trainees, while their European colleagues had enough PPE supply. Our respondents reported that they were able to maintain social distancing inside the hospital compared with their European colleagues (67.3\% vs 9\%). Moreover, the application of COVID-19 testing and regulations on what to do with COVID-19 symptoms were clear to most of the trainees in Europe and Turkey ${ }^{(12)}$. Insufficient training on the management of COVID-19 cases in COVID wards or ICUs or obstetric clinics was reported at a similar rate by Turkish and European trainees (46.5\% vs 50\%, respectively). Turkish and European trainees reported feeling safe at a comparable rate ( 6 vs 6.4 of 10 , respectively). The decrease in educational and surgical activities and number of patients was a worldwide problem during the pandemic, as was reported in Turkey ${ }^{(12,14,15)}$. Patient care was affected as a result of the measures taken. Obstetric care was not changed as reported by $46.5 \%$ of the trainees in Turkey compared with reports by $47 \%$ of the trainees in Europe. However, family planning, reproductive medicine, and gynecological care was reduced significantly in Turkey but was comparable with those in Europe ${ }^{(12)}$.

\section{Conclusion}

The results of this study revealed an overall decrease in outpatient visits, elective surgeries, and educational activities of obstetrics and gynecology residents in Turkey during the COVID-19 pandemic. In this regard, the use of online platforms for educational meetings, providing simulation-based practices, and tele-mentoring of surgical procedures might help trainees complete their residency program without inadequacies.

\section{Ethics}

Ethics Committee Approval: Approval was obtained that there is no need for ethics commission approval for this study.

Informed Consent: Data were collected anonymously from April 29, 2020, to September 5, 2020, by residents after obtaining their informed consent.

Peer-review: Externally peer-reviewed.

\section{Authorship Contributions}

Critical Revision: S.E., Concept: G.T., Design: G.T., S.E., Data Collection or Processing: G.T., İ.B.Ö., Analysis or Interpretation: G.T., Literature Search: G.T., Writing: G.T., İ.B.Ö., S.E.

Conflict of Interest: No conflict of interest was declared by the authors.

Financial Disclosure: The authors declared that this study received no financial support.

\section{References}

1. Furness JB, Callaghan BP, Rivera LR, Cho HJ. The enteric nervous system and gastrointestinal innervation: integrated local and central control. Adv Exp Med Biol 2014;817:39-71.
2. WHO Coronavirus Disease (COVID-19) Dashboard. Available from: https://www.who.int/emergencies/diseases/novelcoronavirus-2019/events-as-they-happen.

3. Perlman S. Another decade, another coronavirus. N Engl J Med 2020;382:760-2.

4. Badahdah AM, Khamis F, Al Mahyijari N. The psychological wellbeing of physicians during COVID-19 outbreak in Oman. Psychiatry Res 2020;289:113053.

5. Republic of Turkey, Ministry of Health, COVID-19 Information page. Available from: https://covid19.saglik.gov.tr/?_Dil=2

6. Aker S, Midık Ö. The Views of Medical Faculty Students in Turkey Concerning the COVID-19 Pandemic. J Community Health 2020;45:684-8

7. Paraiso MFR, Brown J, Abrao MS, Abrão MS, Dionisi H, Rosenfield $\mathrm{RB}$, et al. Surgical and clinical reactivation for elective procedures during the COVID-19 era: a global perspective. J Minim Invasive Gynecol 2020;27:1188-95.

8. Hoopes S, Pham T, Lindo FM, Antosh DD. Home surgical skill training resources for obstetrics and gynecology trainees during a pandemic. Obstet Gynecol 2020;136:56-64.

9. Adesunkanmi AO, Ubom AE, Olasehinde O, Wuraola FO, Ijarotimi OA, Okon NE, et al. Impact of the COVID-19 Pandemic on Surgical Residency Training: Perspective from a Low-Middle Income Country. World J Surg 2021;45:10-7.

10. COVID-19 Pandemisinde Sağlık Kurumlarında Çalışma Rehberi ve Enfeksiyon Kontrol Önlemleri. Available from: https://covid19. saglik.gov.tr/Eklenti/39606/0/covid-19saglikkurumlarindacalismar ehberiveenfeksiyonkontrolonlemleripdf.pdf.

11. Bitonti G, Palumbo AR, Gallo C, Rania E, Saccone G, De Vivo V, et al. Being an obstetrics and gynaecology resident during the COVID-19: impact of the pandemic on the residency training program. Eur $\mathrm{J} \mathrm{Ob}$ Gyn Rep Biol 2020;253:48-51.

12. Boekhorst F, Khattak H, Topcu EG, Horala A, Gonçalves Henriques M. The influence of the COVID-19 outbreak on European trainees in obstetrics and gynaecology: A survey of the impact on training and trainee. Eur J Obstet Gynecol Reprod Biol 2021;261:52-8.

13. Romão GS, Schreiner L, Laranjeiras CLS, Bella ZIKJD, Coelho RA, Simões MDCR, et al. Medical Residency in Gynecology and Obstetrics in Times of COVID-19: Recommendations of the National Specialized Commission on Medical Residency of FEBRASGO. Rev Bras Ginecol Obstet 2020;42:411-4.

14. Pertile D, Gallo G, Barra F, Pasculli A, Batistotti P, Sparavigna M, et al. The impact of COVID-19 pandemic on surgical residency programmes in Italy: a nationwide analysis on behalf of the Italian Polyspecialistic Young Surgeons Society (SPIGC). Updates Surg 2020;72:269-80.

15. Balhareth A, AlDuhileb MA, Aldulaijan FA, Aldossary MY. Impact of COVID-19 pandemic on residency and fellowship training programs in Saudi Arabia: A nationwide cross-sectional study. Ann Med Surg (Lond) 2020;57:127-32.

16. Tolu LB, Feyissa GT, Ezeh A, Gudu W. Managing Resident Workforce and Residency Training During COVID-19 Pandemic: Scoping Review of Adaptive Approaches. Adv Med Educ Pract 2020;11:527-35. 